\title{
Responses of Sargassum thunbergii Germlings to Acute Environmental Stress
}

\author{
Tang Yongzheng ${ }^{*}$, Chu Shaohua, Lu Zhicheng, Yu Yongqiang and Li Xuemeng
}

Ocean School, Yantai University, Yantai 264005, PR China

\begin{abstract}
The responses of Sargassum thunbergii germlings to high temperature, low salinity, desiccation, combined thermal and osmotic stress $\left(35^{\circ} \mathrm{C}\right.$ combined with $\left.12 \mathrm{psu}\right)$, anthracene, and eutrophication were examined. Probit regression analysis results showed that the median lethal time (LT50) values of high temperature decreased with the increase in temperature. The $24 \mathrm{~h}$ median lethal temperature was $36.9^{\circ} \mathrm{C}$. For salinity treatment, the LT50 value of fresh water was $47.6 \mathrm{~h}$. Survival rates of germlings were over $60 \%$ when germlings were exposed to salinities ranging from 27 psu to $7 \mathrm{psu}$ at a time interval of $108 \mathrm{~h}$ post-treatment. The LT50 values of desiccation and combined thermal and osmotic stress $\left(35^{\circ} \mathrm{C}\right.$ combined with $\left.12 \mathrm{psu}\right)$ were $7.0 \mathrm{~h}$ and $9.8 \mathrm{~h}$, respectively. Anovas showed that germlings were inhibited by high concentrations of anthracene $\left(5 \mathrm{mg} \mathrm{L}^{-1}\right.$ and $\left.10 \mathrm{mg} \mathrm{L}^{-1}\right)$ with low survival rates of below $50 \%$ and low relative growth rates of below $1 \%$ after 25 days of culture; however, low concentrations $\left(0.01-1 \mathrm{mg} \mathrm{L}^{-1}\right)$ had no significant effects. In addition, neither severe eutrophication nor disproportionality of N/P showed any significant effect on the survival and growth of germlings. Of the environmental stresses tested, possible occurrence of high temperature of $40{ }^{\circ} \mathrm{C}$ and combined thermal and osmotic stress directly impacted the survival of germlings, suggesting that the deterioration of $\mathrm{S}$. thunbergii bed may be related more to increasing extreme climatic events.
\end{abstract}

Keywords: Environmental stress, germling, median lethal value, Sargassum thunbergii.

\section{INTRODUCTION}

As a member of Sargassum beds, Sargassum thunbergii is ecologically important in the maintenance of a healthy coastal ecosystem [1], such as serving as a primary producer; in spawning, nursery and feeding ground for marine organisms; and as nutrient cycling controller [2]. However, the natural populations of $S$. thunbergii along the coast of China have evidently deteriorated in recent years [3]. It is necessary to explore the reason for this phenomenon. Mostly, deterioration of seaweed beds is caused by various anthropogenic interferences and climate changes which cause increasing extreme events and physical stresses [4]. For example, increased temperature is generally thought to have negative effects on spore production, germination, sporophyte growth and recruitment of seaweeds [5]. Particularly, when they experience periods of temperature change, which are sufficiently high to result in disruptive stress, such damage and any reallocation of resources for protection and repair can cause slow growth, delay development and also lead to mortality [6]. In addition, seaweed growths have declined due to water pollution such as polycyclic aromatic hydrocarbons (PAHs) and eutrophication. Anthracene is a PAH with higher solubility than most other PAHs due to its low molecular capacity and may prove a threat to the environment if widely distributed [7]. It acts as a photosensitizer causing an oxidative damage of algal cells [8]. The eutrophication of coastal zones

*Address correspondence to this author at the Ocean School, Yantai University, yantai, shandong, 264005, P.R. China; Tel: +86 0535 6706010; Fax:+86 0535 6706299; E-mail: yongzht_cn@sina.com resulted from land run-off, river inflow and sewage discharges with an imbalanced N/P ratio can cause harmful algal blooms [9] and deterioration of macroalgal communities [10]. Deeper in water, total algal abundance and abundance of perennial algae decrease along a eutrophication gradient [11]. In brief, both physical and chemical stresses may have adverse effects on the survival of seaweed.

The role of recruitment from germlings in the $S$. thunbergii populations has not been investigated. In other Sargassum species, the role of recruitment from propagules in local persistence and stabilising densities of populations remains controversial [12]. In any case, early stage is a bottleneck for algae [9]. Therefore, it is necessary to test the tolerance of $S$. thunbergii germlings to environmental stresses to search for the reasons of deterioration of $S$. thunbergii bed.

Our previous studies investigated the responses of $S$. thunbergii germlings to combined physical stresses [13]. However, the effects of individual physical and chemical stress are still unknown. Therefore, the present study focuses on the chemical stress and the median lethal values of germlings responding to the individual physical stress. As a common experimental measure of stress tolerance, the acute LD50 (median lethal dose) is used for evaluating tolerance to physical stress due to its high accuracy and flexibility [14]. The lower the value of LD50, the higher is the damage of the stress. The median lethal time was also estimated for the combined thermal and osmotic stress $\left(35^{\circ} \mathrm{C}\right.$ combined with $12 \mathrm{psu}$ ) which previously resulted as extreme for germlings [13]. The objective of this study was to investigate if the 
physical and chemical parameters emerge as environmental stresses for $S$. thunbergii germlings; and if the environmental stresses caused by local (pollution) and overall (climate change) anthropogenic disturbances can explain the deterioration of $S$. thunbergii beds.

\section{MATERIAL AND METHODS}

\subsection{Collection of Germlings}

Fertile female and male specimens of $S$. thunbergii were collected on June 25, 2011, in the intertidal zone of Zhanqiao (373 $\left.1^{\prime} \mathrm{N}, 121^{\circ} 26^{\prime} \mathrm{E}\right)$, Yantai. Selected thalli (about $25 \mathrm{~cm}$ ) were healthy and yellowish-brown in appearance with intact and inflated receptacles which had no obvious shedding. Once transported to the laboratory, they were placed in two $15 \mathrm{~L}$ plastic tanks $(30 \mathrm{~cm} \times 20 \mathrm{~cm} \times 25 \mathrm{~cm})$ filled with filtered seawater which was continuously aerated. Tanks were kept at $25^{\circ} \mathrm{C}, 60 \mu \mathrm{mol}$ photons $\mathrm{m}^{-2} \mathrm{~s}^{-1}$ and with a 10L:14D (light: dark cycle) photoperiod. The irradiance was provided with fluorescent illumination and measured on the water surface.

Released germlings sank to the bottom of tanks within 24 $\mathrm{h}$ after fertilization. Germlings were then collected by filtering the remaining seawater with an 80-mesh nylon sieve, followed by filtration with a 200 -mesh nylon sieve. A total of about $3.0 \times 10^{5}$ germlings were obtained. They were subsequently transferred to a $3 \mathrm{~L}$ glass tank and even stirred to produce a homogeneous suspension.They were then immediately poured into each Petri dish $(60 \mathrm{~mm} \times 15 \mathrm{~mm})$. A total of 109 Petri dishes with about 700 germlings in each were used for the experiment.

\subsection{Stress Treatments}

After $24 \mathrm{~h}$, germlings attached to the Petri dishes were cultured in seven light and temperature-controlled incubators on the basis of the following experimental design. Three independent replicates were used for each treatment. For desiccation treatment, samples were cultured in a total of five durations of desiccation: $3 \mathrm{~h}, 6 \mathrm{~h}, 9 \mathrm{~h}, 10 \mathrm{~h}$ and $12 \mathrm{~h}$. The desiccation treatment was conducted at relative humidity of about $80 \%$. The chosen level of relative humidity was in accordance with that in the sample plot. The relative humidity was measured with a hygrometer and adjusted by placing soaked filter paper or calcium sulfate in three incubators. After desiccation, germlings were fully immersed for $12 \mathrm{~h}$ prior to the record of survival rate.

For hyposalinity treatment, samples were cultured at five levels of salinity: 27, 20, 13, 7 and 0 . Solutions of different salinities were prepared from seawater diluted with distilled water, measured with a salinity hydrometer (GM Manufacturing Co.) and changed on a daily basis.

For anthracene treatment, samples were cultured at seven concentrations of anthracene: $0.01 \mathrm{mg} \mathrm{L}^{-1}, 0.05 \mathrm{mg} \mathrm{L}^{-1}, 0.1$ $\mathrm{mg} \mathrm{L}^{-1}, 0.5 \mathrm{mg} \mathrm{L}^{-1}, 1 \mathrm{mg} \mathrm{L}^{-1}, 5 \mathrm{mg} \mathrm{L}^{-1}$ and $10 \mathrm{mg} \mathrm{L}^{-1}$, respectively. The tests of anthracene were performed on the basis of two controls (germlings in culture with and without $0.5 \%$ DMSO).

A two-way factorial experimental design was used to test the effects of severe eutrophication and disproportionality of $\mathrm{N} / \mathrm{P}$ on germlings, along-with the concentrations of $\mathrm{N}$ and $\mathrm{P}$ as fixed factors [15]. The concentrations of $\mathrm{N}$ and $\mathrm{P}$ sources were designed as $0.072 \mathrm{mg} \mathrm{L}^{-1}, 0.36 \mathrm{mg} \mathrm{L}^{-1}$ and $2 \mathrm{mg} \mathrm{L}^{-1}$ for $\mathrm{N}$; and $0.011 \mathrm{mg} \mathrm{L}^{-1}, 0.03 \mathrm{mg} \mathrm{L}^{-1}$ and $0.3 \mathrm{mg} \mathrm{L}^{-1}$ for $\mathrm{P}$. $\mathrm{NaNO}_{3}$ and $\mathrm{KH}_{2} \mathrm{PO}_{4}$ were added to the seawater as respective $\mathrm{N}$ and $\mathrm{P}$ sources for a final concentration. Therefore, high $\mathrm{N} / \mathrm{P}$ ratios $(0.36 / 0.011,0.36 / 0.03,2 / 0.011$ and $\left.2 / 0.03 \mathrm{mg} \mathrm{L}^{-1}\right)$ and low N/P ratios $(0.072 / 0.03,0.072 / 0.3$ and $\left.0.36 / 0.3 \mathrm{mg} \mathrm{L}^{-1}\right)$ were obtained. In addition, severe eutrophication with normal $\mathrm{N} / \mathrm{P}$ ratio $\left(2 / 0.3 \mathrm{mg} \mathrm{L}^{-1}\right)$ was also included.

The treatments of desiccation, reduced salinity, anthracene and eutrophication listed above were conducted at $25{ }^{\circ} \mathrm{C}$. For high temperature treatment, samples were cultured at six temperature conditions: $35^{\circ} \mathrm{C}, 36^{\circ} \mathrm{C}, 37^{\circ} \mathrm{C}$, $38^{\circ} \mathrm{C}, 39^{\circ} \mathrm{C}$ and $40{ }^{\circ} \mathrm{C}$. The extreme combined condition $(35$ ${ }^{\circ} \mathrm{C}$ combined with salinity of 12 ) was also conducted to estimate the median lethal time. All treatments were cultured at irradiance of $60 \mu \mathrm{mol}$ photons $\mathrm{m}^{-2} \mathrm{~s}^{-1}$ with a $10 \mathrm{~L}: 14 \mathrm{D}$ light: dark cycle. The irradiance within the wavelength range 400-700 nm was measured using a Li-Cor LI-250 light meter equipped with a LI-190SA quantum sensor.

\subsection{Measurements of Survival and Growth}

Prior to the stress treatment, the mean survival rate of germlings in four dishes was measured as the initial survival rate. The survival rate used in the present study was calculated as a ratio of the actual survival rate in the treatment to the initial survival rate. In each dish, germlings were counted in five areas arranged in a cross pattern (the upper, lower, left and right peripheries and the center) under stereoscopy microscope. A total of about 200 germlings were used to calculate the survival rate of each dish. Germlings were classified as dead if they collapsed or were structurally fragmented.

Considering that anthracene and eutrophication may have no evident effects on the survival of germlings, for the treatments of anthracene and eutrophication, growth of germlings was measured in terms of changes in lengths excluding rhizoids at the end of the experiment. Lengths were measured using a microscope with an ocular micrometer in five areas in each Petri dish as mentioned above. The initial mean length of germlings in four dishes was also measured before the stress treatment. A total of 20 germlings in each dish were used to estimate the relative growth rate $\left(\mathrm{RGR}, \% \mathrm{~d}^{-1}\right)$. RGR was calculated as 100 ( $\mathrm{ln}$ $\left.\left(L_{1}\right)-\ln \left(L_{0}\right)\right) / t$, from initial versus final values, where $L_{0}$ and $L_{l}$ are germlings lengths at the start and at the end of treatment, respectively, and $t$ is the length of treatment period calculation in days [16].

\subsection{Statistical Analysis}

All the data were analyzed using SPSS 13.0 for Windows. Median lethal values of temperature, salinity, desiccation and extreme combined condition with $95 \%$ confidence limits (95\% CL) were determined using the probit regression analysis [17]. Probit regression equations were estimated as $\mathrm{Y}=\mathrm{a}+\mathrm{b} \mathrm{X}$; where $\mathrm{Y}$ is the percent of mortality in probit units, $\mathrm{a}$ and $\mathrm{b}$ are the intercept and slope constants, and $\mathrm{X}$ is the log time or log dose of stress. The effects of DMSO and anthracene on the survival of 
germlings were tested by repeated measures ANOVA. Oneway ANOVAs were used to test the effect of DMSO and anthracene on the growth of germlings. Main effects and interactions of $\mathrm{N}$ and $\mathrm{P}$ on the survival of germlings were analyzed by two-way repeated measures ANOVA. A twoway univariate analysis of variance was performed to test the significance of the main effects and interactions on the growth of germlings, with $\mathrm{N}$ and $\mathrm{P}$ as fixed factors. For repeated measured ANOVA, the Huynh-Feldt correction was used to adjust the degrees of freedom when the sphericity assumption was violated (i.e. if Mauchly's test of sphericity was statistically significant at $p<0.05$ ). Tukey's tests were used for post-hoc comparisons. The differences were considered to be statistically significant if the probability value was less than $5 \%(\mathrm{p}<0.05)$.

\section{RESULTS}

\subsection{Acute Physical Stress for Germlings}

For high temperature treatment, the survival rates of germlings decreased with time (Fig. 1). In comparison to the gradual decline of survival rates at $35^{\circ} \mathrm{C}$ and $36^{\circ} \mathrm{C}$, the survival rates decreased sharply to $0 \%$ within $40 \mathrm{~h}$ when exposed to $37{ }^{\circ} \mathrm{C}$ to $40{ }^{\circ} \mathrm{C}$. Especially at $40{ }^{\circ} \mathrm{C}$, the survival rate of $0 \%$ was even recorded at about $10 \mathrm{~h}$ after treatment (Fig. 1). The results of acute thermal stress tests are listed in Table 1. Variation in $\mathrm{LT}_{50}$ values at different temperatures was evident. $50 \%$ mortalities occurred after exposure to $35^{\circ} \mathrm{C}$ and $36^{\circ} \mathrm{C}$ at over $50 \mathrm{~h}$ and $70 \mathrm{~h}$, respectively (Table 1). However, $\mathrm{LT}_{50}$ values decreased sharply from $37^{\circ} \mathrm{C}$ to 40 ${ }^{\circ} \mathrm{C}$ (Table 1). When exposed to $40{ }^{\circ} \mathrm{C}$, the $\mathrm{LT}_{50}$ value was even lower than $5 \mathrm{~h}$ (Table 1). By the end of $24 \mathrm{~h}$ thermal tolerance experiment, the median lethal temperature was estimated as $36.9^{\circ} \mathrm{C}\left(\chi^{2}=73.8, \mathrm{df}=13, p<0.001,95 \% \mathrm{CL}\right.$, $\left.36.6-37.1^{\circ} \mathrm{C}\right)$.

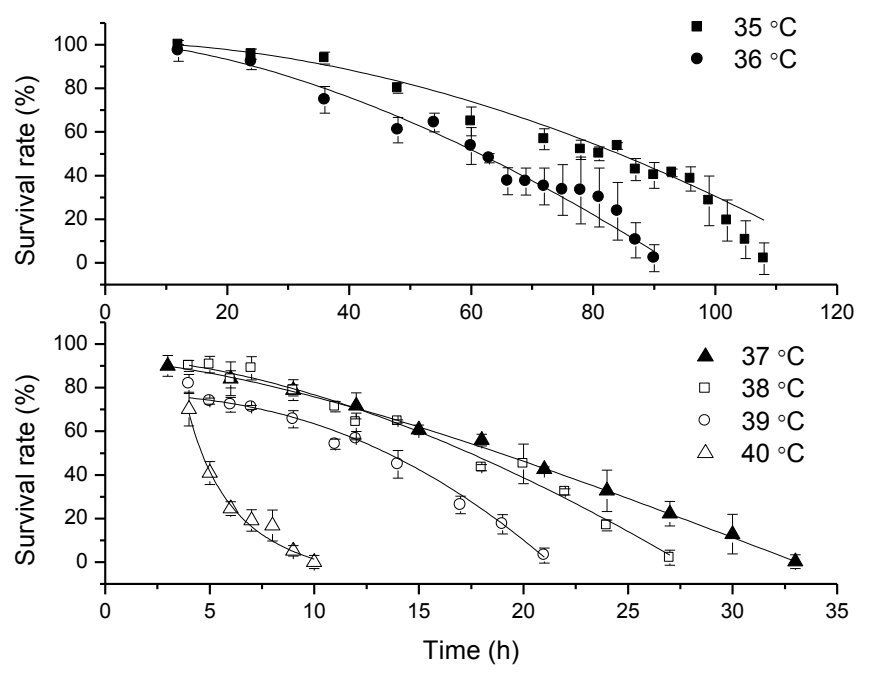

Fig. (1). Survival rates of germlings exposed to various temperatures $\left(35^{\circ} \mathrm{C}, 36^{\circ} \mathrm{C}, 37^{\circ} \mathrm{C}, 38^{\circ} \mathrm{C}, 39^{\circ} \mathrm{C}\right.$ and $\left.40{ }^{\circ} \mathrm{C}\right)$. Solid lines are logistic fits (all $p$ values $<0.01$ and all $\mathrm{R}^{2}$ values $>0.97$ ). Values are means $\pm \mathrm{SE}(\mathrm{n}=3)$.

For hyposalinity treatment, germlings maintained high survival rates at over $90 \%$ when exposed to $27 \mathrm{psu}, 20 \mathrm{psu}$ and 13 psu for $108 \mathrm{~h}$ (Fig. 2). Over 60\% survival rate was obtained after $108 \mathrm{~h}$ exposure to $7 \mathrm{psu}$ (Fig. 2). However, in fresh water, survival rate decreased sharply to about $0 \%$ at a time period of $60 \mathrm{~h}$ (Fig. 2). Probit analysis estimated an $\mathrm{LT}_{50}$ value of $47.6 \mathrm{~h}$ in fresh water (Table $\mathbf{1}$ ).

For desiccation treatment, the survival rates decreased quickly in a short time span and all germlings died at $12 \mathrm{~h}$ (Fig. 3). The $\mathrm{LT}_{50}$ value of desiccation was estimated as 7.0 h (Table 1).

For combined thermal and osmotic stress treatment, the survival rates decreased to about $0 \%$ at $21 \mathrm{~h}$ (Fig. 3). The $\mathrm{LT}_{50}$ value of combined thermal and osmotic stress was estimated as $9.8 \mathrm{~h}$ (Table 1).

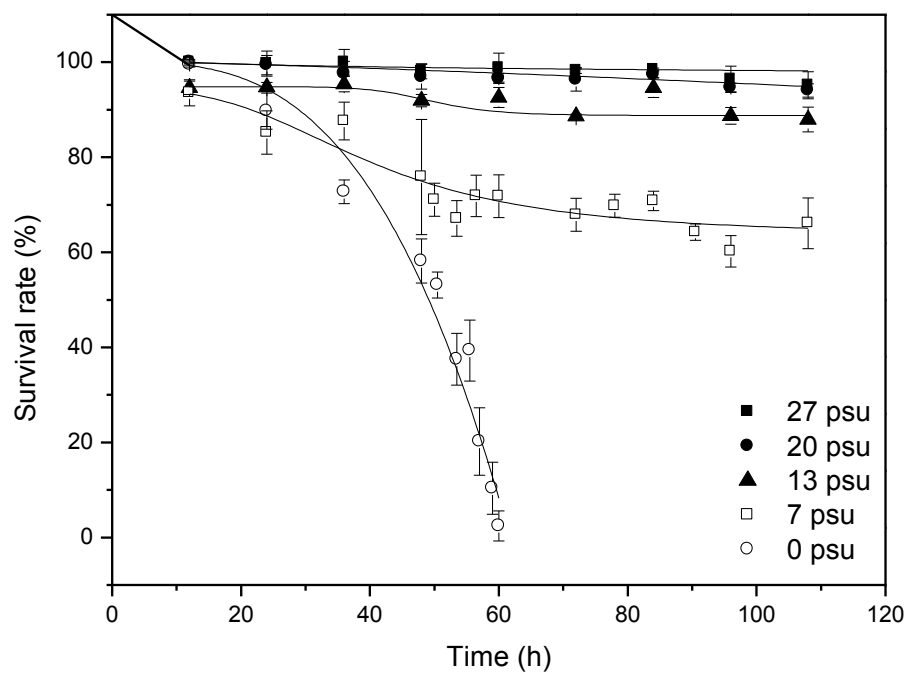

Fig. (2). Survival rates of germlings exposed to various salinities (27 psu, 20 psu, 13 psu, 7 psu and 0 psu). Solid lines are logistic fits (all $\mathrm{p}$ values $<0.01$ and all $\mathrm{R}^{2}$ values $>0.70$ ). Values are means \pm SE $(n=3)$.

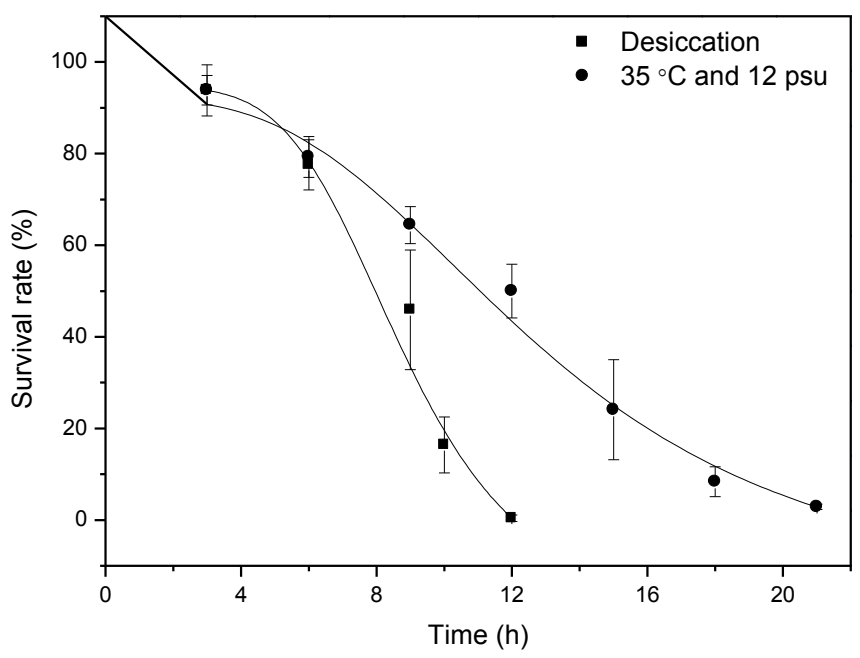

Fig. (3). Survival rates of germlings exposed to desiccation and 35 ${ }^{\circ} \mathrm{C}$ combined with $12 \mathrm{psu}$. Solid lines are logistic fits (all $\mathrm{p}$ values $<$ 0.01 and all $R^{2}$ values $\left.>0.99\right)$. Values are means $\pm S E(n=3)$.

\subsection{Effect of Anthracene on Germlings}

Results of one-way ANOVA indicated that the difference between seawater and DMSO $(0.5 \% \mathrm{v} / \mathrm{v})$ for the growth of germlings was not significant $(F=0.053, p=0.830)$. DMSO also had no significant effect on the survival of germlings 
Table 1. Median lethal time of germlings exposed to various stresses $(n=3)$.

\begin{tabular}{|c|c|c|c|c|c|c|}
\hline \multirow{2}{*}{ Variable } & \multirow{2}{*}{$d f$} & \multirow{2}{*}{$\chi^{2}$} & \multirow{2}{*}{ Regression Equation } & \multirow{2}{*}{$\mathbf{L T}_{50}(\mathrm{~h})$} & \multicolumn{2}{|c|}{ 95\% Confidence Limit (h) } \\
\hline & & & & & Lower & Upper \\
\hline $35^{\circ} \mathrm{C}$ & 49 & $123.7 *$ & $Y=-7.9+4.2 X$ & 77.2 & 74.6 & 12.0 \\
\hline $36^{\circ} \mathrm{C}$ & 40 & $189.0^{*}$ & $Y=-6.1+3.5 X$ & 57.9 & 80.0 & 3.5 \\
\hline $37^{\circ} \mathrm{C}$ & 28 & $155.1^{*}$ & $Y=-3.0+2.5 X$ & 16.4 & 54.3 & 4.8 \\
\hline $38^{\circ} \mathrm{C}$ & 34 & $98.5^{*}$ & $Y=-3.3+2.8 X$ & 15.8 & 61.5 & 45.0 \\
\hline $39^{\circ} \mathrm{C}$ & 28 & $70.5^{*}$ & $Y=-2.5+2.4 X$ & 11.0 & 14.6 & 50.4 \\
\hline $40^{\circ} \mathrm{C}$ & 13 & $63.0^{*}$ & $Y=-2.5+4.0 X$ & 4.3 & 18.4 & 6.2 \\
\hline Fresh water & 22 & $76.6^{*}$ & $Y=-7.9+4.7 X$ & 47.6 & 14.7 & 8.3 \\
\hline Desiccation & 13 & $169.3^{*}$ & $Y=-4.9+5.6 X$ & 7.0 & 17.1 & 8.7 \\
\hline $35^{\circ} \mathrm{C}+12 \mathrm{psu}$ & 19 & $137.6^{*}$ & $Y=-4.0+4.0 X$ & 9.8 & 10.2 & 10.9 \\
\hline
\end{tabular}

* Since Goodness-of-Fit test is significant $(p<0.05)$, a heterogeneity factor is used in the calculation of confidence limits.

(Table 2). Therefore, the interference of $0.5 \%$ DMSO on the growth and survival of $S$. thunbergii germlings can be excluded. Although anthracene significantly affected the survival (Table 2), low concentrations $\left(0.01 \sim 1 \mathrm{mg} \mathrm{L}^{-1}\right)$ had no significant effects (Tukey's tests: $p=0.433, p=0.996, p=$ 0.830 and $p=0.340$, respectively). Survival rates of over $70 \%$ were obtained after 25 days of exposure to concentrations rangeing from $0.01 \mathrm{mg} \mathrm{L}^{-1}$ to $1 \mathrm{mg} \mathrm{L}^{-1}$ (Fig. 4). Similar to the survival effect, although a significant effect of anthracene on the growth of germlings was found $(F=$ $49.360, p<0.001)$, low concentrations of anthracene $(0.01$ $\mathrm{mg} \mathrm{L}^{-1}-1 \mathrm{mg} \mathrm{L}^{-1}$ ) had no significant effects on growth (Tukey's tests, $p=0.510, p=0.982, p=0.163, p=0.676$ and $p=0.234$, respectively). Germlings were severely inhibited by high concentrations of anthracene $\left(5 \mathrm{mg} \mathrm{L}^{-1}\right.$ and $10 \mathrm{mg} \mathrm{L}^{-1}$ ) with low survival rates and RGRs of below $50 \%$ and $1 \%$, respectively (Tukey's tests, $p<0.001$ ) (Fig. 4). The initial mean length of germlings was measured as $127.6 \mu \mathrm{m}$. At the end of anthracene treatment, final lengths ranged from 129.3 to $461 \mu \mathrm{m}$.

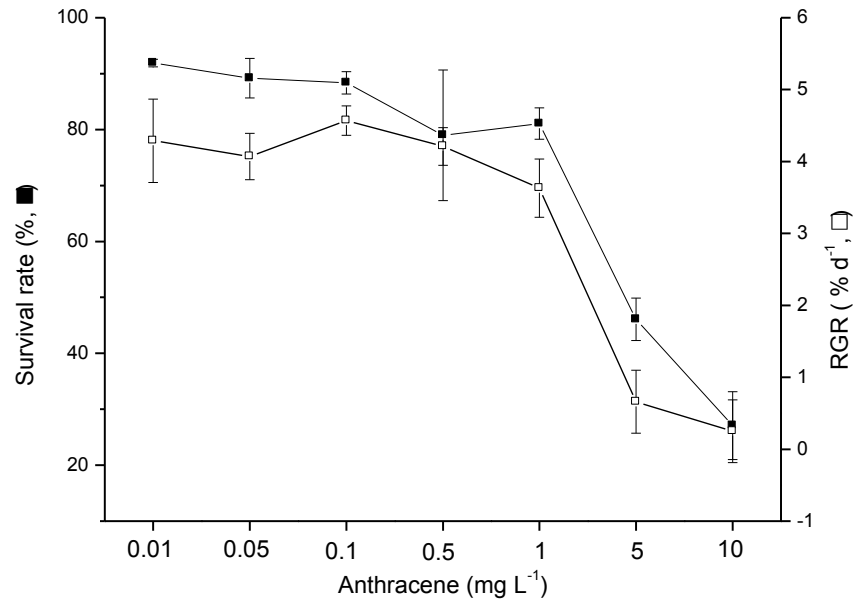

Fig. (4). Relative growth rates (RGR; \% day ${ }^{-1}$ ) and survival rates of germlings exposed to various concentrations of anthracene $(0.01 \mathrm{mg} / \mathrm{L}, 0.05 \mathrm{mg} / \mathrm{L}, 0.1 \mathrm{mg} / \mathrm{L}, 0.5 \mathrm{mg} / \mathrm{L}, 1 \mathrm{mg} / \mathrm{L}, 5 \mathrm{mg} / \mathrm{L}$ and 10 $\mathrm{mg} / \mathrm{L})$ after 25 days of culture. Values are means $\pm \mathrm{SE}(\mathrm{n}=3)$.

\subsection{Effect of Eutrophication on Germlings}

The results of repeated measures ANOVA showed that neither $\mathrm{N}$ nor $\mathrm{P}$ source had significant effect on the survival of germlings (Table 3). No significant effects of $\mathrm{N}$ or $\mathrm{P}$ on the growth were found (Table 4). Therefore, severe eutrophication had little effect on germlings. Tables $\mathbf{3}$ and $\mathbf{4}$ also showed that the interaction between $\mathrm{N}$ and $\mathrm{P}$ source had no significant effects on the survival and growth, indicating that various imbalanced $\mathrm{N} / \mathrm{P}$ ratios also had no effect on germlings. By the end of eutrophication treatment, final lengths of germlings ranged from 227.115 to $344.93 \mu \mathrm{m}$.

\section{DISCUSSION}

Of the environmental stresses tested in the present study, high temperature of $40{ }^{\circ} \mathrm{C}$ and combined thermal and osmotic stress $\left(35^{\circ} \mathrm{C}\right.$ combined with $\left.12 \mathrm{psu}\right)$ may directly impact the survival of germlings.

Although the $\mathrm{LT}_{50}$ value of $39^{\circ} \mathrm{C}$ was evaluated as $11 \mathrm{~h}$, its duration in the mid-tidal zone occupied by $S$. thunbergii cannot exceed the $\mathrm{LT}_{50}$ value even with this temperature, because the temperature decreases due to immersion in seawater during the high tide. This suggests that the high temperature not over $39^{\circ} \mathrm{C}$ causes no mass mortality of $S$. thunbergii germlings in the field. However, the $\mathrm{LT}_{50}$ value of $40{ }^{\circ} \mathrm{C}$ was only about $4 \mathrm{~h}$. Although $S$. thunbergii germlings are rarely exposed to $40{ }^{\circ} \mathrm{C}$ for $4 \mathrm{~h}$ during low tide, this extreme thermal condition possibly occurs under extreme hot weather.

The $\mathrm{LT}_{50}$ value of combined thermal and osmotic stress $\left(35^{\circ} \mathrm{C}\right.$ combined with $12 \mathrm{psu}$ ) was much lower than the separate $\mathrm{LT}_{50}$ values of $35^{\circ} \mathrm{C}$ or 13 psu indicating that there is a synergistic effect between thermal and osmotic stress, that is, germlings living near the limit of one tolerance were more sensitive to additional stress, which is in accordance with the results reported for Fucus vesiculosus [18]. Low salinity usually results from strong rainfall which also causes a decrease in temperature. Hence, high temperature and low 
Table 2. Repeated measures ANOVA for effects of DMSO and anthracene on survival of germlings.

\begin{tabular}{|c|c|c|c|c|c|}
\hline & Variable & $d f$ & Mean Square & $F$ & $p$ \\
\hline \multirow{5}{*}{ DMSO } & Within-subjects & & & & \\
\hline & Time $\times$ DMSO & 24 & 7.264 & 1.565 & 0.066 \\
\hline & Error (Time) & 96 & 4.642 & & \\
\hline & DMSO & 1 & 29.695 & 0.343 & 0.59 \\
\hline & Error & 4 & 86.532 & & \\
\hline \multirow[b]{2}{*}{ Anthracene } & Within-subjects & & & & \\
\hline & Time & 19.174 & 302.948 & 23.310 & $<0.001$ \\
\hline
\end{tabular}

Table 3. Repeated measure ANOVA for effects of $\mathrm{NaNO}_{3}$ and $\mathrm{KH}_{2} \mathrm{PO}_{4}$ on survival of germlings. $\mathrm{N}_{\text {: }} \mathrm{NaNO}_{3}$, $\mathrm{P}: \mathrm{KH}_{2} \mathrm{PO}_{4}$.

\begin{tabular}{|c|c|c|c|c|}
\hline Variable & $d f$ & Mean Square & $F$ & $p$ \\
\hline \multicolumn{5}{|l|}{ Within-Subjects } \\
\hline Time & 4 & 91.923 & 14.428 & $<0.001$ \\
\hline Time $\times \mathrm{N}$ & 8 & 5.178 & 0.813 & 0.594 \\
\hline Time $\times \mathrm{P}$ & 8 & 15.936 & 2.501 & 0.019 \\
\hline Time $\times \mathrm{N} \times \mathrm{P}$ & 16 & 3.847 & 0.604 & 0.871 \\
\hline Error (Time) & 72 & 6.371 & & \\
\hline \multicolumn{5}{|l|}{ Between-Subjects } \\
\hline $\mathrm{N}$ & 2 & 12.68 & 0.394 & 0.680 \\
\hline $\mathrm{P}$ & 2 & 27.278 & 0.849 & 0.444 \\
\hline $\mathrm{N} \times \mathrm{P}$ & 4 & 10.557 & 0.328 & 0.855 \\
\hline Error & 18 & 32.145 & & \\
\hline
\end{tabular}

Dependent variable (survival) was untransformed and the assumption of homogeneity met Levene's test $(F=4.367, p=0.212)$.

salinity can generally not be concurrent with each other in the field. However, extreme climatic events, such as El Niño which can cause high temperatures and storms, may severely destroy S. thunbergii germlings. For example, on the Pacific Coast of California and Baja California, a reduction of the brown algae Macrocystis pyrifera bed size and biomass with up to $100 \%$ in some areas resulted from the influence of El Niño [4].

Table 4. Univariate analysis of variance for effects of $\mathrm{NaNO}_{3}$ and $\mathrm{KH}_{2} \mathrm{PO}_{4}$ on relative growth rate (RGR, \% d $\mathrm{d}^{-1}$ ) of germlings. $\mathrm{N}: \mathrm{NaNO}_{3}, \mathrm{P}: \mathrm{KH}_{2} \mathrm{PO}_{4}$.

\begin{tabular}{|c|c|c|c|c|}
\hline Variable & $\boldsymbol{d} \boldsymbol{f}$ & Mean Square & $\boldsymbol{F}$ & $\boldsymbol{p}$ \\
\hline \hline $\mathrm{N}$ & 2 & $<0.001$ & 1.779 & 0.197 \\
\hline $\mathrm{P}$ & 2 & $<0.001$ & 2.824 & 0.086 \\
\hline $\mathrm{N} \times \mathrm{P}$ & 4 & $<0.001$ & 1.887 & 0.156 \\
\hline Error & 18 & $<0.001$ & & \\
\hline
\end{tabular}

Dependent variable (RGR) was untransformed and the assumption of homogeneity met Levene's test $(F=0.843, p=0.547)$.
The capacity to tolerate desiccation is thought to be a major factor in determining the upper limits of distribution for intertidal seaweed [19]. In comparison to other stresses, germlings were more vulnerable to desiccation at a relative humidity of $80 \%$, which is consistent with our previous study [13]. In contrast, small thallus pieces of Codium fragile (green alga) can survive long periods of emersion (90 days) when kept under high relative air humidity of $90 \%$ [20]. We suggest that desiccation tolerance is related to relative humidity. Therefore, lower relative humidity may have greater adverse effects on $S$. thunbergii germlings in a short span of time. During the low tide, adult canopy can act as a nurse thalli by buffering germlings beneath them from desiccation stress. It is inferred that in the upper tidal zone which is characterized by its long periods of emergence, germlings beneath the adult canopies are the main sources of $S$. thunbergii recruitments.

Intertidal seaweeds are subjected to low salinity stress when exposed to low tide or trapped in tide pools, where fresh water from rain may cause a decrease in salinity [21]. In seaweeds, hypo-osmotic stress causes increases in cell 
volume and turgor, resulting in the loss of ions and organic solutes as well as in damage to membranes and organelles, culminating in cell rupture [22]. However, in this study, $S$. thunbergii germlings exhibited high tolerance to reduced salinity, even in fresh water. Similar phenomena were reported in Fucus. Simulated rainfalls during low tides caused photosynthetic activity of Fucus spiralis to drop to $50 \%$ of initial $\mathrm{Fv} / \mathrm{Fm}$, independent of the length of the rain period. Treated thalli also fully recovered after $6 \mathrm{~min}$ resubmersion in seawater [23]. It suggested that even heavy rain during the low tide cannot result in mass deaths of $S$. thunbergii germlings. Furthermore, extremely low salinity cannot be maintained for a long time due to tidal motions. Therefore, the deterioration of S. thunbergii beds may not be related to hyposalinity resulting from heavy rain.

It has been reported that algae are more tolerant to PAHs than other aquatic organisms [24]. In the present study, $S$. thunbergii germlings also showed high tolerance to anthracene. Although the survival and growth of germlings were significantly affected by the concentration of over $5 \mathrm{mg}$ $\mathrm{L}^{-1}$, the solubility of anthracene in water $\left(0.073 \mathrm{mg} \mathrm{L}^{-1}\right)$ wasmuch lower than its concentration [25]. Although anthracene at $0.25 \mathrm{mg} \mathrm{L}^{-1}$ reduced the growth of three Scenedesmus species [26], growth of S. thungergii germlings was not significantly affected at this concentration. It appears that direct anthracene toxicity is not important in assessing the environmental hazard posed to algae by anthracene and PAH contamination [27]. However, there was a significant interaction between anthracene and UV-A radiation, which, in combination, caused significant toxic effects on Selenastrum capricornutum [27]. Anthracene at nominal concentrations exceeding $0.05 \mathrm{mg} \mathrm{L}^{-1}$ inhibited the growth of the algae in a concentration- and irradiancedependent manner [8]. Therefore, response of S. thunbergii germlings to the interaction between anthracene and irradiance needs further investigation.

Eutrophication can result in accelerated development of the early stages of some algal species [9]. However, in the present study, neither positive nor negative effects of eutrophication on S. thunbergii germlings were found. Effect of $\mathrm{N} / \mathrm{P}$ ratio on marine environment has received great deal of attention. The appearance of different red tides was related to the N/P ratio [28]. Our results showed that N/P ratio had no significant effect on $S$. thunbergii germlings. However, indirect effects including increased sediment cover of substrata, scouring caused by wind-induced resuspension of sediments, and grazing, were also expected to be negative [9]. A deterioration of the light climate due to increased phytoplankton biomass, suspended matter and overgrowing (shading) by epiphytes are likely causes for the decline of Fucus spp. in Kiel Bay [29], and for a decrease in macrophyte numbers in general [30]. Therefore, indirect effects of eutrophication may be partially responsible for the deterioration of $S$. thunbergii beds.

Since the young stages of seaweeds are a sensitive link in species life cycle [18], recovery of populations from anthropogenic stress is likely to depend upon recruitment of these early stages [9]. Pollution of PAHs and eutrophication seems to have little effect on $S$. thunbergii germlings. Although high temperature of $40{ }^{\circ} \mathrm{C}$ and combined thermal and osmotic stress $\left(35^{\circ} \mathrm{C}\right.$ combined with $\left.12 \mathrm{psu}\right)$ directly impacted the survival of germlings, such extreme conditions rarely exist in the middle of the latitude region unless extreme events occur. It is suggested that increasing extreme climatic events caused by various anthropogenic interferences are more responsible for the deterioration of $S$. thunbergii beds and other seaweed beds. These results will be useful in the search for evidence regarding the reasons of deterioration of $S$. thunbergii beds.

\section{CONCLUSION}

As an ecologically important member of Sargassum beds, the natural populations of $S$. thunbergii along the coast of China have evidently deteriorated in recent years. This paper represents the responses of $S$. thunbergii germlings to acute environmental stress. The median lethal time (LT50) values of high temperature, low salinity and combined thermal and osmotic stress $\left(35^{\circ} \mathrm{C}\right.$ combined with $\left.12 \mathrm{psu}\right)$ by Probit regression analysis, and the effects on the survival and growth of germlings of high concentrations of anthracene (5 $\mathrm{mg} \mathrm{L}^{-1}$ and $10 \mathrm{mg} \mathrm{L}^{-1}$ ), low concentrations (0.01-1 $\mathrm{mg} \mathrm{L}^{-1}$ ), severe eutrophication and disproportionality of N/P by anovas, were examined. Results indicated that the deterioration of $S$. thunbergii beds may be related more to the increasing extreme climatic events.

\section{CONFLICT OF INTEREST}

The authors confirm that this article content has no conflict of interest.

\section{ACKNOWLEDGEMENTS}

This work was financially supported by the National Natural Science Foundation of China (NO.41376154) and a Project of Shandong Province Higher Educational Science and Technology Program (J10LC22).

\section{REFERENCES}

[1] Zhang QS, Li W, Liu S, et al. Size-dependence of reproductive allocation of Sargassum thunbergii (Sargassaceae, Phaeophyta) in Bohai Bay, China. Aquat Botany 2009; 91: 194-8.

[2] Zhang SY, Sun HC. Research progress on seaweed bed ecosystem and its engineering. Chinese. J Appl Ecol 2007; 18: 1647-53 (in Chinese with English abstract).

[3] Zhang QS, Tang YZ, Liu SK, et al. Zygote-derived seedling production of Sargassum thunbergii: focus on two frequently experienced constraints in tank culture of seaweed. J Appl Phycol 2012; 24: 707-14.

[4] Terawaki T, Yoshikawa K, Yoshida G, et al. Ecology and restoration techniques for Sargassum beds in the Seto Inland Sea, Japan. Marine Pollut Bull 2003; 47: 198-201.

[5] Buschmann AH, VaAquez J, Osorio P, et al. The effect of water movement, temperature and salinity on abundance and reproductive patterns of Macrocystis spp. (Phaeophyta) at different latitudes in Chile. Marine Biol 2004; 145: 849-62.

[6] Davison I R, Pearson G A. Stress tolerance in intertidal seaweeds. J Phycol 1996; 32: 197-211.

[7] Bonnet J L, Guiraud P, Dusser M, et al. Assessment of anthracene toxicity toward environmental eukaryotic microoganisms: Tetrahymena Pyriformis and selected micromycetes. Ecotoxicol Environ Safety 2005; 60: 87-100.

[8] Aksmann A, Tukaj Z. The effect of anthracene and phenanthrene on the growth, photosynthesis, and SOD activity of the green alga Scenedesmus armatus depends on the PAR Irradiance and CO sub (2) level. Arch Environ Contaminat Toxicol 2004; 47: 177-84.

[9] Coelho SM, Rijstenbil JW, Brown RM. Impacts of anthropogenic 
stresses on the early development stages of seaweeds. J Aquat Ecosyst Stress Recovery 2000; 7: 317-33.

[10] Whitaker SG, Smith JR, Murray SN. Reestablishment of the Southern California rocky intertidal brown alga, Silvetia compressa: an experimental investigation of techniques and abiotic and biotic factors that affect restoration success. Restorat Ecol 2010; 18: 1826.

[11] Krause-Jensen D, Sagert S, Schubert H, et al. Empirical relationships linking distribution and abundance of marine vegetation to eutrophication. Ecolog Indicat 2008; 8: 515-29.

[12] Ang P, De Wreede R. Matrix models for algal life history stages. Marine Ecol- Progress Series 1990; 59: 171-81.

[13] Chu SH, Zhang QS, Liu SK, et al. Tolerance of Sargassum thunbergii germlings to thermal, osmotic and desiccation stress. Aquatic Botany 2012; 96: 1-6.

[14] Fowler DB, Gusta LV, Tayler NJ. Selection for winter-hardiness in wheat: Screening methods. Crop Science 1981; 21: 896-901.

[15] Wang HS, Lei K, Li ZC, et al. Fuzzy comprehensive evaluation of w ater eutrophlcation in Liaodong Bay. Res Environ Sci 2010; 23: 413-9 (in Chinese with English abstract).

[16] Hunt R. Plant Growth Analysis. London: Edward Arnold 1978.

[17] Finney DJ. Probit analysis. Cambridge University Press, Cambridge 1973.

[18] Andersson S, Kautsky L, Kaystdy N. Effects of salinity and bromine on zygotes and embryos of Fucus vesiculosus from the Baltic Sea. Marine Biol 1992; 114: 661-5.

[19] Harker M, Berkaloff C, Lemoine Y, et al. Effects of high light and desiccation on the operation of the xanthophylls cycle in two marine brown algae. Europ J Phycol 1999; 34: 35-42.

[20] Schaffelke B, Deane D. Desiccation tolerance of the introduced marine green alga Codium fragile ssp. tomentosoides - clues for likely transport vectors? Biol Invasions 2005; 7: 557-65.

[21] Macler BA. Salinity effects on photosynthesis, carbon allocation, and nitrogen assimilation in the red alga, Gelidium coulteri. Plant Physiol 1988; 88: 690-4.

[22] Lobban CS, Harrison PJ. Seaweed Ecology and Physiology. Cambridge: Cambridge University Press 1994.

[23] Schagerl M, Möstl M. Drought stress, rain and recovery of the intertidal seaweed Fucus spiralis. Marine Biol 2011; 158: 2471-9.

[24] Cody TE, Radike MJ, Warshawsky D. The phototoxicity of benzo[a]pyrene in the green alga Selenastrum capricornutum. Environ Res 1984; 35: 122-32.

[25] Johannes C, Majcherczyk A, Hüttermann A. Degradation of anthracene by laccase of Trametes versicolor in the presence of different mediator compounds. Appl Microbiol Biotechnol 1996; 46: 313-7

[26] Zbigniew T, Wojciech P. Individual and combined effect of anthracene, cadmium, and chloridazone on growth and activity of SOD izoformes in three Scenedesmus species. Ecotoxicol Environ Safety 2006; 65: 323-31.

[27] Gala WR, Giesy JP. Flow cytometric determination of the photoinduced toxicity of anthracene to the green alga Selenastrum capricornutum. Environ Toxicol Chem 1994; 13: 831-40.

[28] Tseng C K. The past, present and future of phycology in China. Hydrobiologia 2004; 512: 11-20.

[29] Vogt H, Schramm W. Conspicuous decline of Fucus in Kiel Bay (Western Baltic): What are the causes? Marine Ecol Prog Seri 1991; 69: 189-94.

[30] Phillips G, Eminson D, Moss B. A mechanism to account for macrophyte decline in progressively eutrophicated freshwaters. Aquat Botany 1978; 4: 103-26.

(C) Yongzheng et al.; Licensee Bentham Open.

This is an open access article licensed under the terms of the Creative Commons Attribution Non-Commercial License (http://creativecommons.org/licenses/ by-nc/4.0/) which permits unrestricted, non-commercial use, distribution and reproduction in any medium, provided the work is properly cited. 